\title{
前立腺肥大症由来の細胞培養に関する研究
}

\author{
名古屋市立大学医学部泌尿器科学教室 (主任 : 大田黒和生教授)
}

津ヶ谷 正 行 大田黒 和 生

\section{STUDY OF CELL LINES DERIVED FROM BENIGN HYPERTROPHIC PROSTATE TISSUE}

\author{
Masayuki Tsugaya and Kazuo Ohtaguro \\ Department of Urology, Nagoya City University Medical School
}

(Director: Prof. K. Ohtaguro)

\begin{abstract}
Primary epithelial and fibroblast cells from benign hypertrophic prostate tissue were established. The prostate tissues were obtained by transurethral resection of the prostate or retropubic prostatectomy in patients with benign prostatic hypertrophy. Growth factors for cultured epithelial cells and fibroblasts were studied. The epithelial cells grew well in the WAJC-404 culture medium with insulin, epidermal growth factor and dexamethasone. Fibroblasts grew well in culture medium containing $10 \%$ fetal calf serum. The prostate tissue was stored at $4^{\circ} \mathrm{C}$ for 7 days and no degenerative change in the stromal cells was seen during this period. Although epithelial cells did degenerate with the passage of time, epithelial cells cultured after storage for 4 days at $4^{\circ} \mathrm{C}$ behaved similarly to those cultured immediately after being isolated. These primary cultures of epithelial cells and fibroblasts from hypertrophic prostate may be useful for various studies.
\end{abstract}

Key words: benign prostatic hypertrophy, epithelial cell culture, fibroblast culture

\begin{abstract}
要旨：前立腺肥大症患者における TUR-P や被膜下前立腺摘除術で得られた組織から上皮細胞と線維芽 細胞それぞれの初代培養を確立し，上皮細胞と線維芽細胞の増殖に関与する因子を検討した。 上皮細胞 培養における細胞増殖は WAJC-404培地に insulin, EGF と dexamethasone の 3 者を添加した培地にお いて盛んであった。線維芽細胞培養における細胞増殖では培養液に添加する FCS の濃度は10\%で良好な

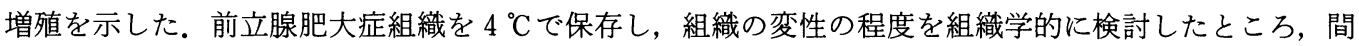
質組織では 7 日間保存後でも変性は認められなかったが，上皮細胞は経時的に変性細胞が増加した。し かし, 前立腺肥大症組織を $4{ }^{\circ} \mathrm{C} て ゙ 4$ 日間保存後培養したところ, 上皮細胞は保存期間に関係なく, 即日 培養したときと同様の増殖を示した. 以上のように TUR-P の検体が使用でき，また 4 日間冷所保存が可 能である前立腺の上皮細胞と線維芽細胞それぞれの初代培養は手軽で利用価值が高い培養法と考えられ る. キーワード：前立腺肥大症，上皮細胞培養，線維芽細胞培養
\end{abstract}

緒 言

前立腺の上皮細胞と線維芽細胞それぞれの生理機 能，殊に種々のホルモン，薬剤や増殖因子に対する応 答，上皮細胞と線維芽細胞における細胞間の相互関係 ならびに腫瘍の発生や病理などを解明するため, 一つ の有用なる手段として主にラットの前立腺細胞を用い

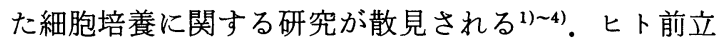
腺由来の上皮細胞と線維芽細胞のそれぞれが容易に培 養できれば上記諸問題の解明に役立つ。著者らはヒト 前立腺肥大症由来の上皮細胞と線維芽細胞それぞれの
初代培養を確立し，上皮細胞と線維芽細胞それぞれの 増殖に関与する因子を検討したので報告する。

\section{方法}

前立腺肥大症患者における経尿道的前立腺切除術 (TUR-P) や被膜下前立腺摘除術で得られた組織約 $2 \mathrm{~g}$ を200IU/ml の penicillin と $200 \mu \mathrm{g} / \mathrm{ml}$ の streptomycin を加え，また $5 \%$ fetal calf serum（FCS）を加え た RPMI-1640培地（RPMI 1640 medium, LGlutamine, penicillin, streptomycin と FCS は GIBCO 社製） $10 \mathrm{ml}$ 中に入れて実験室に運んだ。得ら 
れた組織を約 $10 \mathrm{ml} の$ balanced salt solution（以下 MSS と称し，その組成は $\mathrm{NaCl}=28.28 \mathrm{~g}, \mathrm{KCl}=0.6 \mathrm{~g}$, glucose $=2.88 \mathrm{~g}, \mathrm{KH}_{2} \mathrm{PO}_{4}=0.544 \mathrm{~g}, \mathrm{HEPES}=28.6 \mathrm{~g}$, phenol red 3.3 $\mu \mathrm{M}$ で，蒸留水に $4 \mathrm{~N}$ の $\mathrm{NaOH}$ を加兄 て全量 $4,000 \mathrm{ml}, \mathrm{pH} 7.6$ に調整した）で振盪し，3回 洗浄した後，シャーレ上で $2 \sim 4 \mathrm{~mm}$ 注どの立方体の細 片とし，200IU $/ \mathrm{ml}$ の penicillin と200 $\mu \mathrm{g} / \mathrm{ml}$ の streptomycin を加光,さらに $200 \mathrm{U} / \mathrm{ml}$ collagenase(Worthington collagenase \#4196 specific activity greater $160 \mathrm{U} / \mathrm{mg}$ ) 添加の $5 \% \mathrm{FCS}$ 加 RPMI-1640培地で $37^{\circ} \mathrm{C}$, 20時間, shaker 上で incubate した. その後, pipetting を数回施行した。この digest した組織液を遠心管に移 し，約 $10 \mathrm{ml}$ の MSSを加えて振盪混和し，1,069.0G $(2,400 \mathrm{rpm}) 10$ 分間遠心し，この操作をさらに 2 回繰り 返して，collagenase を除去した。沈澱した細胞塊に5 $\mathrm{ml}$ の RPMI-1640培地を加兄て振盪混和して，185.6G $(1,000 \mathrm{rpm}) 20$ 秒間遠心し，上皮細胞と線維芽細胞を分 離した。沈澱した上皮細胞は無血清の WAJC-404培地 (極東製薬工業社製)，線維芽細胞は RPMI-1640培地で 培養した。

I ．上皮細胞培養に打ける細胞増殖の検討

下記 6 種類の培養液を作製し，T25細胞培養用フラ スコで初代培養を開始してから 2 日目，4 日目，6日 目に上皮細胞総数を顕微鏡下でコロニ一の大きさとそ れぞれの細胞数から算定した。

(1) WAJC-404培地単独

(2) WAJC-404培地に insulin $2.5 \mu \mathrm{g} / \mathrm{ml}$ を添加

(3) WAJC-404培地にbovine hypothalamus extract（以下 BHE と略す） $20 \mu \mathrm{g} / \mathrm{ml}$ を添加

(4) WAJC-404培地に epidermal growth factor 10 $\mathrm{ng} / \mathrm{ml}$ (以下 $\mathrm{EGF}$ と略す) を添加

(5) WAJC-404培地に insulin $2.5 \mu \mathrm{g} / \mathrm{ml}$ と dexamethasone $1 \mu \mathrm{M}$ を添加

(6) WAJC-404培地に insulin $2.5 \mu \mathrm{g} / \mathrm{ml}$, EGF $10 \mathrm{ng} /$ $\mathrm{ml}$ と dexamethasone $1 \mu \mathrm{M}$ を添加

また，上記培養液に $100 \mathrm{IU} / \mathrm{ml} の$ penicillin と 100 $\mu \mathrm{g} / \mathrm{ml}$ の streptomycin を加えた。

II. 線維芽細胞培養における細胞増殖の検討

下記 7 種類の培養液を作製し，24-well 細胞培養プ レートでそれぞれ培養し，7日目の細胞数を算定した。

(1) RPMI-1640培地に $5 \% \mathrm{FCS}$ を添加

(2) RPMI-1640培地に $5 \% \mathrm{FCS}$, insulin $2.5 \mu \mathrm{g} / \mathrm{ml}$, $\mathrm{EGF} 10 \mathrm{ng} / \mathrm{ml}$ を添加

(3) RPMI-1640培地に10\%FCS を添加
(4) Dulbecco's Modified Eagle 培地に $5 \%$ FCS 添加

(5) Dulbecco's Modified Eagle 培地に10\%FCSを 添加

(6) Dulbecco's Modified Eagle 培地に10\%FCS, insulin $2.5 \mu \mathrm{g} / \mathrm{ml}$ を添加

(7) Dulbecco's Modified Eagle 培地に10\%FCS, insulin $2.5 \mu \mathrm{g} / \mathrm{ml}$, BHE $20 \mu \mathrm{g} / \mathrm{ml}$ を添加

また，上記培養液に $100 \mathrm{IU} / \mathrm{ml}$ の penicillin と 100 $\mu \mathrm{g} / \mathrm{ml}$ の streptomycin を加えた。

III. 前立腺肥大症組織を $200 \mathrm{IU} / \mathrm{ml} の$ penicillin と $200 \mu \mathrm{g} / \mathrm{ml}$ の streptomycinを加光た $5 \% \mathrm{FCS}$ 加 RPMI-1640培地に入れ， $4{ }^{\circ} \mathrm{C}$ で 1 日間， 4 日間， 7 日 間保存後, 組織の変性の程度を組織学的に検討した。

IV. 前立腺肥大症組織を $200 \mathrm{IU} / \mathrm{ml}$ の penicillin と $200 \mu \mathrm{g} / \mathrm{ml}$ の streptoycin を加えた 5 \%FCS 加 RPMI1640培地または前記抗生剂を加えた生理的食塩水中に

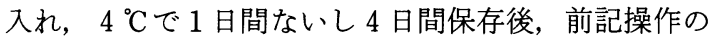
後に WAJC-404培地に insulin $2.5 \mu \mathrm{g} / \mathrm{ml}$, EGF 10ng/ $\mathrm{ml}$, dexamethasone $1 \mu \mathrm{M}$, penicillin $100 \mathrm{IU} / \mathrm{ml}$ と streptomycin $100 \mu \mathrm{g} / \mathrm{ml}$ を添加した培養液で培養し た。培養 7 日目に上皮細胞の増殖状態を検討する目的 で，フラスコ底に増殖した上皮細胞が占める割合を計 測した。組織重量によって $\mathrm{T} 25 \mathrm{~cm}^{2}$ フラスコと T75 $\mathrm{cm}^{2}$ フラスコを使用したため, $\mathrm{T} 25 \mathrm{~cm}^{2}$ フラスコ当たり の組織重量を算定し,さらに組織 $1 \mathrm{~g}$ 当たりの増殖した 上皮細胞がフラスコ底で占める割合として算定した。

\section{結 果}

I 。上皮細胞培養に拈ける細胞増殖の検討

Fig. 1 に示したように WAJC-404培地に insulin や

Fig. 1 Relationship between epithelial cell growth and medium composition.

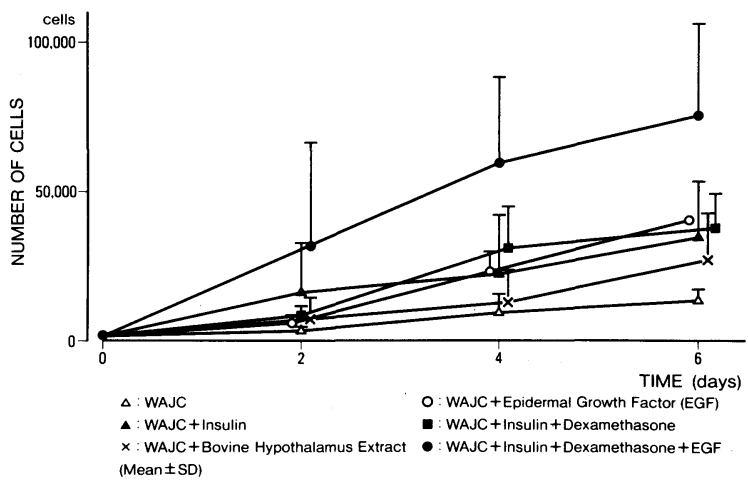


Table 1 Relationship between medium composition and fibroblast cell growth after 7 days in primary culture

\begin{tabular}{l|c|c|c|c|c|c|c}
\hline $\begin{array}{c}\text { Patient } \\
\text { (sample) }\end{array}$ & $\begin{array}{c}\text { RPMI } \\
5 \% \text { FCS }\end{array}$ & $\begin{array}{c}\text { RPMI } \\
5 \% \text { FCS } \\
\text { Insulin } \\
\text { EGF }\end{array}$ & $\begin{array}{c}\text { RPMI } \\
10 \% \text { FCS }\end{array}$ & $\begin{array}{c}\text { EAGLE } \\
5 \% \text { FCS }\end{array}$ & $\begin{array}{c}\text { EAGLE } \\
10 \% \text { FCS }\end{array}$ & $\begin{array}{c}\text { EAGLE } \\
10 \% \text { FCS } \\
\text { Insulin }\end{array}$ & $\begin{array}{c}\text { EAGLE } \\
10 \% \text { FCS } \\
\text { Insulin } \\
\text { BHE }\end{array}$ \\
\hline H.A. & - & & - & \pm & & & \\
M.C. & \pm & - & + & + & & & \\
H.P.-1 & - & - & $-m$ & + & + & & \\
H.P.-2 & - & - & - & + & + & & \\
J.I. & \pm & - & + & \pm & + & \pm & + \\
E.M.-1 & - & \pm & \pm & \pm & + & + & + \\
E.M.-2 & - & - & - & \pm & + & - & \pm \\
\hline
\end{tabular}

- : No fibroblasts

$\pm: 1-10$ fibroblasts/well (24-well plate)

$+: 11-20$ fibroblasts/well (24-well plate)

\# : 21-30 fibroblasts/well (24-well plate)

$\mathrm{WH}:$ More than 31 fibroblasts/well (24-well plate)

FCS : fetal calf serum. BHE : bovine hypothalamus extract.

EGF 単独あるいは insulin と dexamethasone を添加 した培地では上皮細胞の増殖は不十分であったが， WAJC-404培地に insulin $2.5 \mu \mathrm{g} / \mathrm{ml}$, EGF $10 \mathrm{ng} / \mathrm{ml}$ と dexamethasone $1 \mu \mathrm{M}$ の 3 者を添加した培地において 上皮細胞の増殖が盛んであった。統計上では, WAJC404培地単独に比べてWAJC-404培地に insulin と dexamethasone を加えた培地の方が増殖が盛んで, 培 養 2 日目ならびに 2 者の全体の比較で有意差が認めら れた $(\mathrm{p}<0.05)$. しかし，その他の培地の比較では検 体数が少なく，ばらつきが大きいため有意差は認めら れなかった。

\section{II。線維芽細胞培養における細胞増殖の検討}

Table 1 に示したように insulin, EGF, BHEの添 加は線維芽細胞培養における細胞增殖を促進しなかっ た。 insulinはむしろ細胞増殖を抑制する傾向を示し た. 培養液に添加する FCS の濃度は $5 \%$ に比べて $10 \%$ の方が良好な増殖を示した。

III. 前立腺肥大症組織を $4{ }^{\circ} \mathrm{C}$ で保存し, 組織の变性 の程度を組織学的に検討したところ, 間質組織では 7 日間保存後でも変性は認められなかった。 上皮細胞は その部位によって多少異なるが, 経時的に变性細胞が 増加した (Table 2). Table 2 の Case No. T.C. 7日 目の検体には間質組織のみで，上皮細胞がなかった。

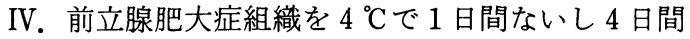
保存後培養したところ, 保存期間に関係なく上皮細胞 は増殖した（Table 3).

V. 上記実験の結果を通じて, 上皮細胞と線維芽細
Table 2 Pathological characteristics of degenerating prostatic epithelial cells cultured afer a period of storage in RPMI 1640 with $5 \%$ FCS and antibiotics

\begin{tabular}{c|c|c|c|c}
\hline Patient & Not stored & 1 day & 4 days & 7 days \\
\hline H. E. & - & - & Slightly & Some \\
T. N. & None & None & Mild & Some \\
T. C. & None & Some & Mild & No epithelium \\
N.W. & None & Some & Mild & Many \\
A. L. & None & Mild & Some & Many \\
\hline
\end{tabular}

Not stored: cultured immediately. None: no degenerative change. Slightly: slightly degenerative changes. Some : some degenerative changes. Mild : mild degenerative changes. Many : many degenerative changes. No epithelium : no epithelium in the specimen.

胞の培養を確立した。 その方法を Fig. 2 に示した。培 養された上皮細胞と線維芽細胞を Fig. 3，4 に示した. なお immunocytochemical stainingで上皮細胞は cytokeratin 陽性で, 線維芽細胞は vimentin 陽性で あった。

\section{考察}

ヒトの前立腺上皮の細胞培養は原組織が硬く, 酵素 処理による細胞間の分離が困難なことから組織片から out-grow した細胞を対象として行われてきた4)55. 種々の collagenase による細胞の分離, さらにラット 前立腺腹葉上皮細胞の無血清培地による培養が成功 $し^{2)}$, ヒトの前立腺上皮の細胞培養に発展した ${ }^{7) 8}$. 血清 
Table 3 Primary epitheial cell cultures: Relation between cell growth and tissue storage time.

\begin{tabular}{|c|c|c|c|c|c|c|c|}
\hline $\begin{array}{l}\text { Patient } \\
\text { (sample) }\end{array}$ & Age & $\begin{array}{c}\text { Storage } \\
\text { time (days) }\end{array}$ & Medium & $\begin{array}{l}\text { Weight of tissue } \\
\pi \mathrm{T} 25 \mathrm{~cm}^{2} \text { flask (grm.) } \\
\text { [A] }\end{array}$ & $\begin{array}{l}\text { Area of flask covered with } \\
\text { cells after } 7 \text { days }(\%) \\
\text { [B] }\end{array}$ & \multicolumn{2}{|c|}{$\begin{array}{c}{[B] \div[A]} \\
(M e a n \pm S D)\end{array}$} \\
\hline W.F.-1 & 72 & 0 & RPMI & 1.27 & 65 & 51.2 & \\
\hline H.E. & 75 & 1 & RPMII & 0.66 & 85 & 128.8 & \\
\hline T. N. & 61 & 1 & RPMI & 0.34 & 40 & 117.5 & \\
\hline J.E. & 78 & 1 & RPMI & 0.67 & 25 & 37.3 & \\
\hline J.G.-1 & 55 & 1 & RPMI & 0.41 & 85 & 207.3 & \\
\hline J. G. -2 & 55 & 1 & Saline & 0.41 & 90 & 219.5 & \\
\hline J. B. -1 & 69 & 1 & RPMI & 0.88 & 40 & 45.5 & $126.4 \pm$ \\
\hline P.P. & 64 & 1 & Saline & 0.62 & 80 & 129.0 & .70.5 \\
\hline A. L.-1 & 75 & 2 & RPMI & 1.00 & 80 & 80.0 & \\
\hline A. L. -2 & 75 & 2 & RPMI & 0.11 & 20 & 181.8 & \\
\hline W. N.-1 & 75 & 2 & RPMI & 0.63 & 75 & 119.1 & $178.5 \pm$ \\
\hline W.N.-2 & 75 & 2 & RPMI & 0.21 & 70 & 333.3 & 111.4 \\
\hline M. C. & 64 & 3 & RPMI & 1.08 & 10 & 9.3 & \\
\hline \multirow[t]{2}{*}{ J. B. -4} & 69 & 1 & Saline & & & & \\
\hline & & 2 & RPMI & 1.03 & 30 & 29.1 & \\
\hline E. M. -1 & 82 & 3 & RPMI & 0.71 & 75 & 105.6 & \\
\hline E. M.-2 & 82 & 3 & Saline & 0.76 & 70 & 92.1 & $52.2 \pm$ \\
\hline J. B. -5 & 69 & 3 & Saline & 0.80 & 20 & 25.0 & 43.5 \\
\hline T. C.-1 & 62 & 4 & RPMI & 0.17 & 65 & 382.4 & \\
\hline \multirow[t]{2}{*}{ T. C. -2} & 62 & 1 & Saline & & & & \\
\hline & & 3 & RPMI & 0.71 & 80 & 112.7 & \\
\hline H. P.-1 & 58 & 4 & RPMI & 0.91 & 50 & 55.0 & 140.4士 \\
\hline H. P. -2 & 58 & 4 & Saline & 0.87 & 10 & 11.5 & 166.6 \\
\hline
\end{tabular}

Fig. 2 Methods of primary culture of cells derived from benign hypertrophic prostate Prostatic tissue (BPH)

Collect and store the tissue in RPMI 1640 with $5 \%$ FCS and antibiotics at $4^{\circ} \mathrm{C}$

$\downarrow$

Wash the tissue with MSS solusion three times

Mince the tissue into small pieces

Incubate the tissue in RPMI 1640 with $5 \%$ FCS, antibiotics and $200 \mathrm{U} / \mathrm{ml}$ of collagenase for 20 hours at $37^{\circ} \mathrm{C}$ with constant shaking

Collect the mixture and centrifuge it at $1069.0 \mathrm{G}$ (2400 rpm.) for 10 minutes, wash the cells with MSS solusion

Suspend the cells in RPMI 1640 and centrifuge the cells at $185.6 \mathrm{G}(1000 \mathrm{rpm}$.) for 20 seconds

Deposits

Culture the acini with

WAJC 404 medium, $2.5 \mu \mathrm{g} / \mathrm{ml}$ of insulin, $1 \mu \mathrm{M}$ of dexamethasone, $10 \mathrm{ng} / \mathrm{ml}$ of EGF, antibiotics

$$
5 \% \mathrm{CO}_{2}: 95 \% \text { air at } 37^{\circ} \mathrm{C}
$$

$$
\downarrow
$$

Change the medium on Day 3

$$
\downarrow
$$

Growth of epithelial cells

$$
\downarrow
$$

Detach the cell using $600 \mathrm{U} / \mathrm{ml}$ of collagenase

Subculture
Supernatant

Culture the cells with

RPMI 1640 with $10 \%$ FCS, antibiotics
Change the medium on Day 3 and 10<smiles>[AlH2]</smiles>

Growth of fibroblast cells

$$
\downarrow
$$

Detach the cell using tripsin

Subculture 
Fig. 3 Epithelial cell culture, $\times 300$.

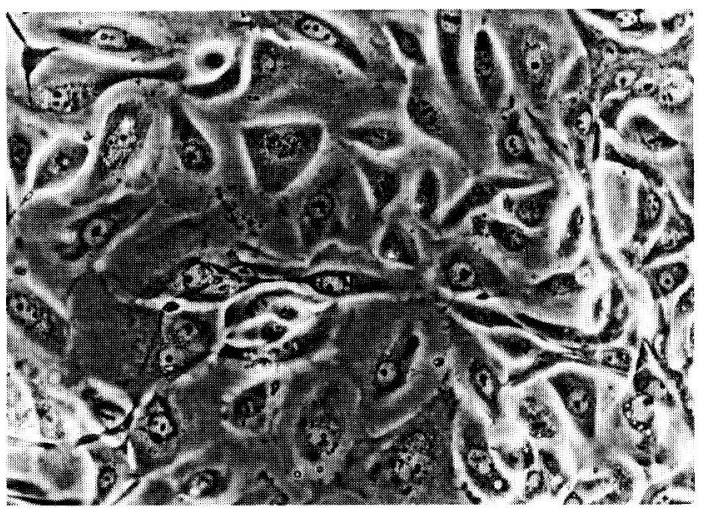

Fig. 4 Fibroblast cell culture, $\times 300$.

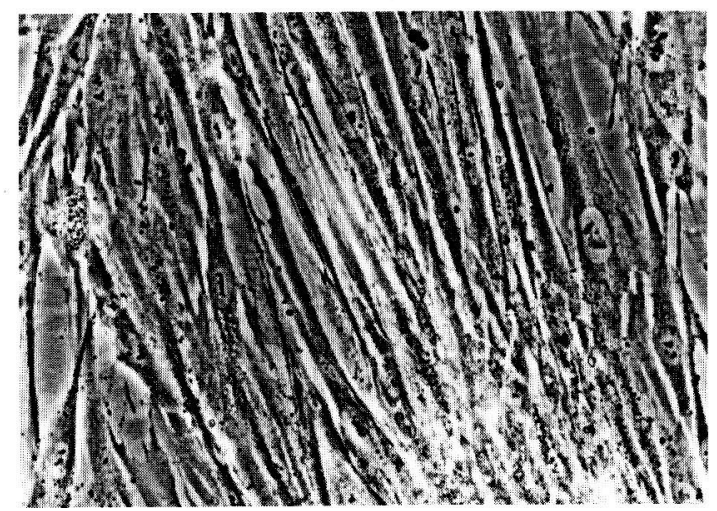

を含まない培養液では成分が明らかであるため，細胞 増殖に関与した化学物質や成長因子, そしてその濃度 の影響が観察でき，さらに細胞の代謝を捉光ることが 容易となるため前立腺に㧍ける研究の実験系として極 めて有用である. insulin は上皮細胞の増殖を促進する が, $10^{-1} \mathrm{IU} / \mathrm{ml}$ 以上ではその効果が低下し，EGF とは 相加的に増殖を促進するとされている。 また dexamethasone $は 10^{-8} \mathrm{M}$ の濃度で細胞増殖が最も盛んに なり, insulin との併用ではその濃度によって細胞増殖 は抑制されるとされている ${ }^{9) 10)}$. 著者の実験に用いた dexamethasone と insulin の濃度では増殖抑制は認め られず, 今回 dexamethasone 単独添加群における増 殖細胞数の算定は行わなかったが，スラスコ上での発 育状態の観察では単独添加より併用の医うが良好で あった，BHEは上皮細胞の増殖促進には重要な日子 を含んでいるとされているが8), 今回の検討では期待 するほどの効果は得られなかった. dexamethasone, insulin と EGF との 3 者併用は相乗的効果は認められ なかったが, 増殖効果は最も良好で, 相加的効果であっ た。増殖細胞数の算定は行わなかったが, 増殖促進効 果があるとされている $\mathrm{BHE}^{8) や ~ c h o l e r a ~ t o x i n 7 を 上 ~}$ 記 3 者とともに添加しても増殖促進効果が認められな かった. 上皮細胞の初代培養では急速に増殖を示すが， 培養10日以降扣よび継代培養においてはその増殖速度 は緩慢となる．肥大症由来の細胞であるため悪性細胞 と本質的に異なることが原因であり，上記種々の成長 因子を組み合わせてもこの時期に种ける細胞増殖効果 は得られなかった。

前立腺肥大症組織は尿路閉塞による尿路感染を伴 ことが多く，前立腺自体が感染し，しばしば微小膿痬 を伴っている. 経康道的前立腺切除術で得られた組織 片を主に用いたため，培養の初期段階で細菌感染した ことによる培養の失敗は少なくなかった。組織自体の 感染を伴わなくても尿路感染や術中操作中に細菌が付 着寸ることが考えられ，抗生物質を通常の 2 倍(200

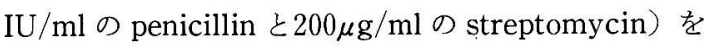
転送用溶液や collagenase の溶液に加えた。 その結果, 細菌感染による頻度は減少した。.また組織が得られて 直ぐに細胞培養するより $4{ }^{\circ} \mathrm{C}$ で保存して翌日以降に培 養操作をする方が成功率が高かった。

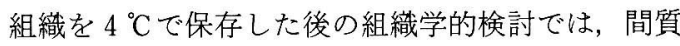
組織の変性は7日までは，特に認められなかった。し かし，上皮組織では程度の差，部位による差はみられ るものの経時的に変性が認められた。このように変性 が認められる上皮組織から細胞培着を行らことは困難 と考学られたが，実際には $4{ }^{\circ} \mathrm{C} て ゙ 4$ 日間以内の保存で あれば，保存期間に関係なく上皮細胞の培養が可能で あった。このように 4 日間程度の組織保存の後に細胞 培養ができることは，日常診療に忙しい泌尿器科医が 研究と両立する上で，極めて有用な実験系である，組 織学的に変性が認められても，細胞培養がでさること は，分化し，古くなった細胞は死隇し，原始的かつ未 熟な細胞が培養されたものと考えられる。TUR-Pで 得られた検体は電気メスによる組織損傷が強く，被膜 下摘除術に比べて細胞増殖が劣る印象を持ったが，検 体によっては増殖の良好なものもあり，一定の傾向は 得られなかった。

皮膚や他臓器の線維芽細胞培養は数多くの報告があ り，前立腺肥大症の培養も行われている。いずれも培 養液に血清が添加されて扣り，今回の結果のように線 維芽細胞の増殖には血清濃度が重要な要素であった。 
初代培養における線維芽細胞の増殖は極めて遅いが, スラスコの底を満たす時点から増殖速度は速く, 約 3 日間で 2 倍に増殖した。このような時点で血清濃度を $10 \%$ から $5 \%$ に低下させたところ, 細胞の維持は可能 であったが，増殖速度は低下した，上皮細胞と線維芽 細胞の両者を分離，培養するため collagenase を使用 した。この collagenase が線維芽細胞を障害のるること も考兄られ, collagenase 溶液による incubationの時 間を短縮してみたが，その効果は認められなかった。

上皮細胞と線維芽細胞の両者を分離し, その培養を 確立することは上皮細胞と間質細胞の相互関係, 成長 因子，ホルモン代謝やホルモン非依存性の獲得，コレ ステロールを主とする脂質代謝さらに薬剤の効果とそ の作用機序の検討等をさらに追求するために有用であ る.今回の研究では前立腺癌組織を得る機会がほとん ぞなかったためその培養を確立できなかった，前立腺 癌細胞の培養においては肥大症の場合と異なるにせよ このような方法を生かすことができると考光る。その ための参考として著者らの経験を付記した。

\section{結 語}

1）ヒト前立腺肥大症由来の上皮細胞と線維芽細胞 それぞれの初代培養を確立し, 上皮細胞と線維芽細胞 それぞれの増殖に関与する因子を検討した。

2）上皮細胞培養に抢ける細胞増殖を検討したとこ ろ WAJC-404培地に insulin, EGF と dexamethasone の 3 者を添加した培地に批いて上皮細胞の増殖が盛ん であった。

3）線維芽細胞培養における細胞増殖では insulin, $\mathrm{EGF}, \mathrm{BHE}$ の添加は細胞増殖を促進せず, insulinは むしろ細胞增殖を抑制する傾向を示した。培養液に添 加する FCS の濃度は $5 \%$ に比べて $10 \%$ の方が良好な 増殖を示した。

4) 前立腺肥大症組織を $4{ }^{\circ} \mathrm{C} て ゙$ 保存し, 組織の変性の 程度を組織学的に検討したところ, 間質組織では 7 日 間保存後でも変性は認められなかった。 上皮細胞は経 時的に変性細胞が増加した。しかし，前立腺肥大症組 織を $4{ }^{\circ} \mathrm{C} て ゙ 1$ 日間ないし 4 日間保存後培養したとこ ろ，保存期間に関係なく上皮細胞は増殖した。

5）上記実験の結果を通じて, 上皮細胞と線維芽細胞 の培養を確立し，その方法を記述した。

稿を終えるにあたり，御愳切なる御指導を賜わりました 英国エジンバラ大学医学部泌尿器外科学教室 G.D. Chisholm 教授ならびに F.K. Habib 助教授に深謝いたしま す.
なお本研究はASSOCIATION FOR INTERNATIONAL CANCER RESEARCH の補助金の援助を受け た.

本論文の要旨は第78回日本泌尿器科学会総会（札幌, 1990）で発表した。

\section{文 献}

1) Ofner, P., Vena, R.L., Terracio, L. and Douglas, W.H.J.: Comaparative $\mathrm{C}_{19}$-radiosteroid metabolism in primary monolayer cultures of epithelial cells and fibroblasts from rat ventral prostate, canine prostate, and rat lung. J. Androl., 3, 269-280, 1982.

2) McKeehan, W.L., Adams, P.S. and Rosser, M. P.: Direct mitogenic effects of insulin, epidermal growth factor, glucocorticoid, cholera toxin, unknown pituitary factors and possibly prolactin, but not androgen, on normal rat prostate epithelial cells in serum-free, primary cell culture. Cancer Res., 44, 1998-2010, 1984.

3) Nishi, N., Matuo, Y., Nakamoto, T. and Wada, F.: Proliferation of eplithelial cells derived from rat dorsolateral prostate in serum-free primary cell culture and their response to androgen. In Vitro Cellular Developmental Biology, 24, 778-786, 1988.

4) Chung, L.W.K., Chang, S., Bell, C., Zhau, H., Ro, J.Y. and von Eschenbach, A.C.: Prostatic carcinogenesis evoked by cellular interaction. Envionmental Health Perspectives, 77, 23-28, 1988.

5) Stonington, O.G. and Hemmingsen, H.: Culture of cells as a monolayer derived from the epithelium of the human prostate: A new cell growth technique. J. Urol., 106, 393-400, 1971.

6) Peehl, D.M., Wong, S.T., Terris, M.K. and Stamey, T.A.: Culture of prostatic epithelial cells from ultrasound-guided needle biopsies. Prostate, 19, 141-147, 1991.

7) Peehl, D.M.: Serial culture of adult human prostatic epithelial cells. J. Tissue Culture Methods, 9, 53-60, 1985.

8) Chaproniere, D.M. and Mckeehan, W.L. : Serial culture of single adult human prostatic epithelial cells in serum-free medium containing low calcium and a new growth factor from bovine brain. Cancer Res., 46, 819-824, 1986.

9) Chaproniere, D.M. and Webber, M.M.: A chemically defined medium for the growth of adult human prostatic epithelium. Cold Spring Harbor Conferences Cell Proliferation, 2, 1109-1115, 1982.

10) Chaproniere, D.M. and Webber, M.M.: Dexamethasone and retinyl acetate similarly inhibit and stimulate EGF- or insulin-induced proliferation of prostatic epithelium. J. Cell. Physiol., 122, 249-253, 1985.

（1993年 2 月 1 日受付， 7 月 9 日受理） 